\title{
Esophageal Squamous Cell Carcinoma Location Category $\mathrm{X}$
}

National Cancer Institute

\section{Source}

National Cancer Institute. Esophageal Squamous Cell Carcinoma Location CategoryX. NCI Thesaurus. Code C133392.

Esophageal squamous cell carcinoma with unknown location. (from AJCC 8th Ed.) 